\title{
Pengungkapan Corporate Social Responsibility dan Penghindaran Pajak dengan Profitabilitas sebagai Variabel Moderasi
}

\author{
Ni Made Artini ${ }^{1}$ \\ Fakultas Ekonomi dan Bisnis \\ Universitas Udayana, Indonesia
}

\author{
Putu Ery Setiawan ${ }^{2}$ \\ Fakultas Ekonomi dan Bisnis \\ Universitas Udayana, Indonesia
}

\begin{abstract}
Surel : artinimade568@gmail.com
ABSTRAK

Penelitian ini memiliki tujuan guna memperoleh bukti empiris mengenai pengaruh pengungkapan Corporate Social Responsibility (CSR) terhadap penghindaran pajak dengan profitabilitas sebagai variabel pemoderasi. Penelitian menggunakan perusahaan sektor pertambangan yang telah terdaftar di Bursa Efek Indonesia (BEI) periode 2017-2019 sebagai populasi. Jumlah pengamatan sebanyak 75 sampel diperoleh melalui metode nonprobability sampling dengan teknik purposive sampling. Pengumpulan data dilakukan dengan metode observasi non partisipan. Teknik Moderated Regression Analysis (MRA) digunakan untuk menganalisis data. Hasil penelitian yang dilakukan menunjukkan bahwa pengungkapan CSR berpengaruh negatif pada penghindaran pajak. Profitabilitas sebagai variabel pemoderasi mampu memoderasi pengaruh pengungkapan CSR pada penghindaran pajak.
\end{abstract}

Kata Kunci: Corporate Social Responsibility; Profitabilitas; Penghindaran Pajak.

\section{Disclosure of Corporate Social Responsibility and Tax Avoidance with Profitability as Moderating Variable}

\footnotetext{
ABSTRACT

This study aims to obtain empirical evidence regarding the effect of Corporate Social Responsibility (CSR) on tax avoidance with profitability as a moderating variable. This research was conducted at mining sector companies listed on the Indonesia Stock Exchange (BEI) for the 2017-2019 period. The number of observations of 75 samples obtained through nonprobability sampling method with purposive sampling technique. Data collection was carried out by non-participant observation method. The data analysis technique used is Moderated Regression Analysis (MRA). The results showed that CSR disclosure had a negative effect on tax avoidance. Profitability as a moderating variable is able to moderate the effect of CSR disclosure on tax avoidance.

Keywords: Corporate Social Responsibility; Profitability; Tax Avoidance.
}

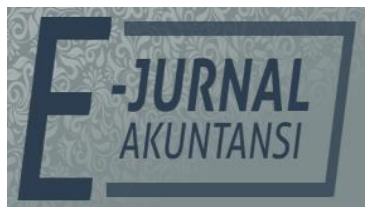

e-ISSN 2302-8556

Vol. 31 No. 9

Denpasar, September 2021 Hal. 2277-2288

DOI:

10.24843/EJA.2021.v31.i09.p10

PENGUTIPAN:

Artini, N.M., \& Setiawan, P.E.

(2021). Pengungkapan

Corporate Social Responsibility dan Penghindaran Pajak dengan Profitabilitas sebagai Variabel Moderasi. E-Jurnal Akuntansi, 31(9), 2277-2288

RIWAYAT ARTIKEL:

Artikel Masuk: 4 Januari 2021 Artikel Diterima: 25 Februari 2021

Artikel dapat diakses : https://ojs.unud.ac.id/index.php/Akuntansi/index 


\section{PENDAHULUAN}

Penerimaan negara yang terbesar salah satunya bersumber dari penerimaan pajak. Pajak sebagai pendapatan negara dapat membantu pemerintah dalam menunjang pembangunan. Realitanya, penerimaan pajak yang diterima oleh pemerintah Indonesia saat ini belum mencapai hasil yang maksimal. Data penerimaan pajak periode 2015-2019 menunjukkan bahwa pemerintah Indonesia belum mampu merealisasikan target penerimaan pajak yang telah ditetapkan. Berikut disajikan perbandingan target dan realisasi penerimaan pajak.

Tabel 1. Target dan Realisasi Penerimaan Pajak Indonesia Periode 2015-2019

\begin{tabular}{cccc}
\hline \multirow{2}{*}{ Tahun } & \multicolumn{2}{c}{ Penerimaan Pajak } & \multirow{2}{*}{ Pencapaian Target (\%) } \\
\cline { 2 - 3 } & Target (Rp triliun) & Realisasi (Rp triliun) & \\
\hline 2015 & $1.489,3$ & $1.240,4$ & 83,3 \\
2016 & $1.539,2$ & $1.285,0$ & 83,5 \\
2017 & $1.283,6$ & $1.147,5$ & 89,4 \\
2018 & $1.424,0$ & $1.315,9$ & 92,4 \\
2019 & $1.786,4$ & $1.545,3$ & 86,5 \\
\hline
\end{tabular}

Sumber: Direktorat Jenderal Pajak, 2020

Berdasarkan Tabel 1, ditunjukkan bahwa Pemerintah Indonesia telah berhasil meningkatkan penerimaan pajaknya selama 5 (lima) tahun terakhir sebesar Rp 1.240,4 triliun pada 2015 menjadi Rp 1.545,3 triliun pada 2019. Kenaikan penerimaan pajak selama 5 (lima) tahun terakhir tidak berarti bahwa penerimaan pajak telah mencapai target yang ditetapkan. Realitanya, penerimaan pajak tahun 2016 merupakan yang terendah dalam pencapaian targetnya yaitu sebesar 81,61 persen dari target yang ditetapkan.

Pungutan pajak yang bersifat memaksa menyebabkan wajib pajak baik pribadi maupun badan melakukan tindakan perlawanan pajak. Bagi wajib pajak badan, pembayaran pajak merupakan kewajiban bagi perusahaan sehingga akan mengurangi laba yang diperoleh perusahaan. Hal tersebut menyebabkan beberapa perusahaan berusaha mencari celah untuk mengurangi pembayaran pajak, dan tidak menutup kemungkinan perusahaan akan menjadi agresif dalam perpajakan.

Tax avoidance (penghindaran pajak) adalah tindakan sebagai upaya mengurangi jumlah pembayaran pajak secara legal dan aman tanpa melanggar ketentuan perpajakan yang berlaku. Penghindaran pajak secara sadar dilakukan oleh perusahaan untuk memperkecil jumlah pembayaran pajak kepada pemerintah. Penghindaran pajak merupakan salah satu skema untuk meminimalkan beban pajak dengan memanfaatkan berbagai aspek kelemahankelemahan (grey area) yang ada dalam ketentuan perpajakan.

Perusahaan yang telah go-public dan terdaftar di Bursa Efek Indonesia (BEI) diharapkan untuk memperhatikan dampak sosial dan lingkungan. Menurut Undang-Undang RI No. 40 tahun 2007 tentang Perseroan Terbatas, perseroan yang melakukan kegiatan usaha dibidang dan/atau yang berhubungan dengan sumber daya alam (SDA) memiliki kewajiban untuk melaksanakan tanggung jawab sosial dan lingkungan (CSR). CSR tidak hanya terbatas pada konsep pemberian bantuan dana kepada sosial dan lingkungan masyarakat, tetapi juga terkait bagaimana perusahaan memperlakukan dan mengayomi karyawan dengan tidak diskriminatif serta menjaga hubungan baik dengan pemasok. Tindakan 
penghindaran pajak yang dilakukan oleh perusahaan tidak melanggar hukum yang ada, tetapi masyarakat menilai tindakan tersebut merupakan tindakan yang tidak bertanggungjawab terhadap lingkungan sosial (Hidayat et al., 2018).

Rasio profitabilitas adalah rasio atau perbandingan untuk mengetahui kemampuan perusahaan dalam memperoleh laba dari keseluruhan pendapatan yang diperoleh. Profitabilitas adalah salah satu faktor yang dikatakan dapat mempengaruhi timbulnya agresivitas pajak (Prasista \& Setiawan, 2016). Profitabilitas digunakan sebagai variabel moderasi karena secara teoretis semakin tinggi tingkat profitabilitas yang dicapai perusahaan maka semakin kuat pula hubungan pengungkapan CSR dengan penghindaran pajak.

Teori yang digunakan dalam penelitian ini adalah teori legitimasi dan teori stakeholder. Teori legitimasi didasarkan atas adanya peristiwa kontak sosial antara masyarakat dan juga organisasi. Organisasi atau perusahaan wajib memiliki tujuan yang selaras dengan nilai/norma yang ada dalam masyarakat. Tujuannya tentu saja agar organisasi mendapatkan legitimasi dari masyarakat sehingga mampu mempertahankan kelangsungan hidupnya (Wijaya, 2019). Salah satu bentuk legitimasi yang dapat dilakukan oleh perusahaan adalah dengan melakukan aktivitas tanggung jawab sosial atau yang biasa disebut Corporate Social Responsibility (CSR).

Berdasarkan teori stakeholder, perusahaan merupakan organisasi yang tidak hanya beroperasi demi kepentingannya sendiri tetapi juga mempunyai tanggung jawab sosial serta dituntut untuk dapat memberikan manfaat bagi stakeholder-nya (Chairi, 2008). Sesuai dengan teori ini, perusahaan memiliki tanggung jawab sosial yang mengharuskan mereka untuk mempertimbangkan kepentingan semua pihak yang terkena dampak dari aktivitas perusahaan.

Sesuai dengan teori legitimasi, perusahaan akan berupaya untuk memperoleh pengakuan atau legitimasi dari masyarakat melalui kegiatan tanggung jawab sosial. Pengungkapan CSR adalah bentuk komunikasi perusahaan mengenai dampak aktivitas operasi perusahaan terhadap lingkungan alam dan sosial pada stakeholder. CSR merupakan salah satu bentuk tanggung jawab perusahaan kepada stakeholder. Melakukan pembayaran pajak secara jujur adalah bentuk tanggung jawab perusahaan kepada stakeholder melalui pemerintah. Kesadaran perusahaan akan pentingnya pajak bagi masyarakat dan negara dapat berdampak pada citra perusahaan yang dianggap semakin peduli dengan tanggung jawab sosialnya. Hal ini sejalan dengan penelitian yang dilakukan oleh Prasista \& Setiawan (2016) yang menyatakan bahwa pengungkapan CSR berpengaruh negatif pada agresivitas pajak. Dengan demikian, semakin tinggi tingkat tanggung jawab sosial yang dilakukan perusahaan, maka semakin rendah kemungkinan perusahaan melakukan penghindaran pajak. Sesuai dengan uraian tersebut, maka dapat dirumuskan hipotesis sebagai berikut.

$\mathrm{H}_{1}$ : Pengungkapan Corporate Social Responsibility berpengaruh negatif terhadap

Penghindaran Pajak.

Rasio profitabilitas yang digunakan dalam penelitian ini adalah return on assets (ROA). Perusahaan dengan profitabilitas tinggi memiliki kecenderungan untuk melaporkan beban pajaknya secara jujur dibandingkan dengan perusahaan yang mempunyai profitabilitas rendah. Hal ini sejalan dengan penelitian yang 
dilakukan oleh Prasista \& Setiawan (2016) dalam penelitiannya yang menemukan hasil bahwa profitabilitas yang diukur dengan return on assets (ROA) berpengaruh negatif pada agresivitas pajak.

Perusahaan yang melakukan pembayaran pajak secara jujur sesuai dengan besarnya laba perusahaan, secara tidak langsung telah menunjukkan kontribusinya kepada kepentingan umum. Hal ini berarti bahwa perusahaan dengan profitabilitas tinggi semakin peduli dengan tanggung jawab sosialnya sehingga perusahaan akan mengurangi tindakan penghindaran pajak karena perusahaan sadar akan pentingnya kontribusi pajak bagi masyarakat. Sesuai dengan uraian tersebut, maka dapat dirumuskan hipotesis sebagai berikut.

$\mathrm{H}_{2}$ : Profitabilitas memoderasi pengaruh CSR terhadap Penghindaran Pajak.

Penelitian ini menggunakan perusahaan sektor pertambangan tahun 20172019 yang terdaftar di Bursa Efek Indonesia (BEI). Peneliti memilih perusahaan pertambangan sebagai objek penelitian karena perusahaan pertambangan merupakan bagian dari industri pengelola sumber daya alam dan salah satu wajib pajak yang berkontribusi besar pada penerimaan pajak negara. Selain itu, perusahaan pertambangan merupakan perusahaan yang menjadi pusat perhatian pemerintah karena Indonesia merupakan negara yang kaya akan sumber daya mineral dan batu bara.

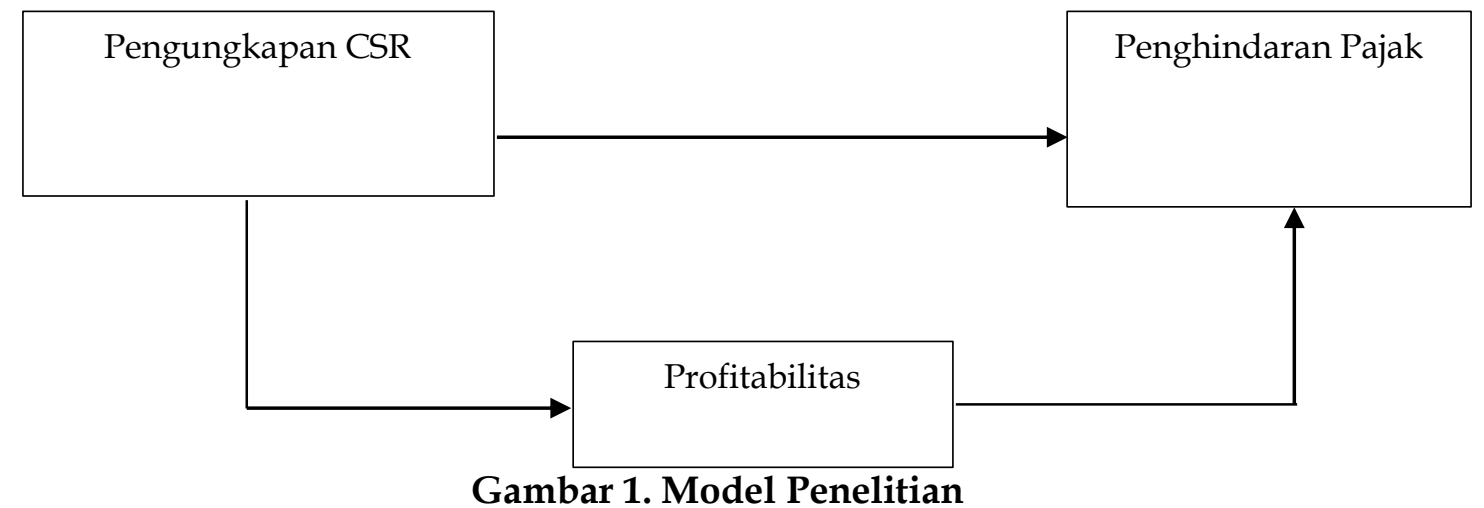

Sumber: Data Penelitian, 2020

\section{METODE PENELITIAN}

Penelitian ini menggunakan pendekatan kuantitatif dengan metode asosiatif. Penelitian dilakukan pada Wajib Pajak Badan perusahaan pertambangan yang terdaftar di Bursa Efek Indonesia (BEI) pada tahun 2017-2019. Obyek dalam penelitian ini adalah penghindaran pajak yang dilakukan oleh perusahaan pertambangan selama tahun amatan. Jenis data yang digunakan dalam penelitian ini adalah data kuantitatif berupa laporan keuangan perusahaan pertambangan dan data kualitatif yang berkaitan dengan penelitian ini dalam bentuk literatur, artikel dan buku. Jenis data yang digunakan yaitu data sekunder berupa laporan keuangan tahunan perusahaan pertambangan yang diperoleh dari website BEI (www.idx.com).

Sesuai dengan permasalahan yang diteliti, maka variabel yang digunakan dalam penelitian ini yaitu, pengungkapan CSR sebagai variabel independen, penghindaran pajak sebagai variabel dependen, dan profitabilitas sebagai variabel moderasi. Pedoman intensitas pengungkapan CSR menggunakan Global Reporting 
Initiative Reporting G4. Pengukuran pengungkapan CSR dilakukan dengan pemberian skor untuk tiap indikator pengungkapan CSR dalam laporan tahunan perusahaan. Skor 1 diberikan jika indikator diungkapkan pada laporan tahunan dan skor 0 jika perusahaan tidak mengungkapkan indikator pada laporan tahunan. Selanjutnya, skor dari setiap indikator dijumlahkan untuk memperoleh hasil akhir keseluruhan untuk setiap perusahaan. Hasil akhir pengungkapan yang didapatkan dari masing-masing perusahaan selanjutnya dihitung indeksnya menggunakan proksi Corporate Social Responsibility Index (CSRI), dengan rumus sebagai berikut.

$\mathrm{CSRI}=\frac{\sum \mathrm{Xyi}}{\mathrm{ni}}$

Keterangan:

CSRI = Corporate Social Responsibility Index

$\sum$ Xyi $=$ Jumlah skor pengungkapan CSR

$\mathrm{Ni}=$ Jumlah item CSR perusahaan (91 item)

Proksi yang digunakan untuk menemukan tingkat penghindaran pajak pada penelitian ini adalah Effective Tax Rates (ETR). Nilai ETR yang semakin tinggi menunjukkan tingkat penghindaran pajak semakin rendah. Hal ini menunjukkan adanya arah yang berlawanan antara ETR dengan penghindaran pajak. Untuk mempermudah interpretasi, peneliti akan mengubah ETR menjadi ETR Invers untuk dianalisis. ETR Invers menunjukkan hubungan searah antara nilai ETR dengan penghindaran pajak. Maka, Nilai ETR Invers yang semakin rendah menandakan semakin rendah kemungkinan penghindaran pajak. Rumus proksi ETR yang digunakan sejalan dengan penelitian yang dilakukan oleh Prasista \& Setiawan (2016) sebagai berikut.

ETR $=\frac{\text { Beban Pajak Penghasilan }}{\text { Laba Sebelum Pajak }}$

Proksi yang digunakan dalam penelitian ini untuk mengukur profitabilitas adalah Return On Assets (ROA). ROA dapat dirumuskan sebagai berikut.

ROA $=\frac{\text { Laba Bersih }}{\text { Total Aset }}$

Populasi dalam penelitian ini adalah seluruh perusahaan pertambangan yang terdaftar di Bursa Efek Indonesia (BEI) periode 2017-2019 sebanyak 41 perusahaan. Metode yang digunakan dalam penentuan sampel adalah metode non probability sampling dengan teknik purposive sampling. Kriteria tersebut antara lain, pertama perusahaan wajib terdaftar di BEI selama tahun amatan yaitu 2017-2019. Kedua, perusahaan menyajikan laporan keuangan tahunan dan mengungkapkan laporan Corporate Social Responsibility. Ketiga, perusahaan memiliki laba positif selama tahun pengamatan.

Pengumpulan data dilakukan dengan metode observasi non partisipan. Metode observasi non partisipan merupakan teknik pengumpulan data yang mana peneliti tidak terlibat langsung dan hanya menjadi pengamat independen. Teknik analisis data yang digunakan dalam penelitian ini adalah Moderated Regression Analysis (MRA) dengan program aplikasi SPSS. Adapun tahapan analisis data yang dilakukan adalah uji statistik deskriptif, uji asumsi klasik, analisis regresi sederhana dan moderasi, koefisien determinasi, uji kelayakan model serta pengujian hipotesis. 


\section{HASIL DAN PEMBAHASAN}

Berdasarkan teknik purposive sampling, diperoleh jumlah sampel yang memenuhi kriteria sebanyak 25 perusahaan dengan total data observasian sebanyak 75 data selama tiga tahun penelitian. Adapun proses pemilihan sampel dijabarkan pada Table 2, berikut.

\section{Tabel 2. Jumlah Sampel Penelitian}

\begin{tabular}{llcc}
\hline No & Kriteria & $\begin{array}{c}\text { Jumlah } \\
\text { Perusahaan }\end{array}$ & Akumulasi \\
\hline 1. & $\begin{array}{l}\text { Perusahaan pertambangan yang terdaftar di BEI } \\
\text { tahun 2017-2019 }\end{array}$ & 41 & 123 \\
2. & Tidak mengungkapkan laporan Corporate Social & 0 & 0 \\
& $\begin{array}{l}\text { Responsibility } \\
\text { 3. }\end{array}$ & $(16)$ & 48 \\
$\quad$ Total observasi tahun 2017-2019 & 25 & 75
\end{tabular}

Sumber: Data Penelitian, 2020

Pengujian statistik deskriptif digunakan untuk mendapatkan informasi mengenai karakteristik variabel-variabel penelitian Data statistik diolah dengan menggunakan software SPSS 26. Hasil statistik deskriptif dari masing-masing variabel disajikan dalam Tabel 3, berikut.

Tabel 3. Hasil Statistik Deskriptif Variabel Penelitian

\begin{tabular}{lccccc}
\hline \multicolumn{1}{c}{ Variabel } & $\mathrm{N}$ & Minimum & Maximum & Mean & $\begin{array}{c}\text { Standard } \\
\text { Deviation }\end{array}$ \\
\hline ETR Invers $(\mathrm{Y})$ & 75 & 0,5025 & 4,9492 & 3,2609 & 0,9536 \\
CSRI (X) & 75 & 0,6484 & 0,9011 & 0,8485 & 0,0304 \\
ROA $(\mathrm{Z})$ & 75 & 0,0014 & 0,2900 & 0,0848 & 0,0688 \\
\hline
\end{tabular}

Sumber: Data Penelitian, 2020

Tabel 3, menunjukkan bahwa jumlah amatan selama periode penelitian ini sebanyak 75. Hasil uji statistik deskriptif menunjukkan bahwa proksi ETR Invers, CSRI, dan ROA memiliki nilai standar deviasi lebih rendah dari nilai rata-rata (mean), menunjukkan bahwa sebaran data penelitian merata atau perbedaan data satu dengan data lain tidak tergolong tinggi. Tahap uji selanjutnya yaitu uji asumsi klasik yang terdiri atas, uji normalitas, uji heteroskedastisitas, dan uji autokorelasi. Uji normalitas bertujuan untuk mengetahui apakah dalam residual dari model regresi yang dibuat berdistribusi normal ataukah tidak. Uji normalitas dalam penelitian ini menggunakan metode Kolmogorov-Smirnov.

Tabel 4. Hasil Uji Normalitas

\begin{tabular}{clccc}
\hline No & \multicolumn{1}{c}{ Persamaan } & $\mathrm{N}$ & $\begin{array}{c}\text { Kolmogorov } \\
\text { Smirnov } \mathrm{Z}\end{array}$ & $\begin{array}{c}\text { Asymp. Sig. (2- } \\
\text { tailed) }\end{array}$ \\
\hline 1 & $\mathrm{Y}=\mathrm{\alpha}+\beta_{1} \mathrm{X}+\varepsilon$ & 75 & 2,224 & 0,071 \\
2 & $\mathrm{Y}=\mathrm{\alpha}+\beta_{1} \mathrm{X}+\beta_{2} \mathrm{Z}+\beta_{3} \mathrm{XZ}+\varepsilon$ & 75 & 2,088 & 0,061 \\
\hline
\end{tabular}

Sumber: Data Penelitian, 2020

Berdasarkan hasil dari Tabel 4, dapat dilihat bahwa persamaan model pertama memiliki nilai Asymp. Sig. (2-tailed) sebesar 0,071 $\geq 0,05$ serta persamaan model kedua memiliki nilai Asymp. Sig. (2-tailed) sebesar 0,061 $\geq 0,05$. Hasil ini menunjukkan bahwa kedua model persamaan regresi berdistribusi normal. Uji heteroskedastisitas memiliki tujuan untuk menguji apakah dalam model regresi terjadi ketidaksamaan varians dari residual satu pengamatan ke pengamatan lain. Uji heteroskedastisitas diperoleh melalui uji Glejser. 
Tabel 5. Hasil Uji Heteroskedastisitas

\begin{tabular}{lcc}
\hline \multicolumn{1}{c}{ Variabel } & Sig. & Keterangan \\
\hline Pengungkapan CSR (X) & 0,113 & Bebas Heteroskedastisitas \\
Profitabilitas (Z) & 0,586 & Bebas Heteroskedastisitas \\
Interaksi Pengungkapan CSR dengan & 0,093 & Bebas Heteroskedastisitas \\
Profitabilitas (XZ) & &
\end{tabular}

Sumber: Data Penelitian, 2020

Berdasarkan pada Tabel 5, nilai Sig. dari variabel pengungkapan CSR (X) sebesar 0,113, variabel profitabilitas $(Z)$ sebesar 0,586 serta variabel interaksi pengungkapan CSR dengan profitabilitas sebesar 0,093. Nilai Signifikansi masingmasing variabel lebih besar dari 0,05 yang berarti bahwa tidak terdapat pengaruh antara variabel independen terhadap absolute residual sehingga dapat ditarik kesimpulan bahwa dalam model regresi tidak terdapat gejala heteroskedastisitas.

Uji autokorelasi memiliki tujuan untuk menguji apakah pada model regresi terdapat korelasi/hubungan antara kesalahan pengganggu pada periode $t$ dengan kesalahan pengganggu pada periode $\mathrm{t}-1$. Dalam penelitian ini uji autokorelasi digunakan dengan pendekatan Durbin-Watson (DW test).

Tabel 6. Hasil Uji Autokorelasi

\begin{tabular}{cccccc}
\hline No & \multicolumn{1}{c}{ Persamaan } & $\mathrm{dL}$ & $\mathrm{dU}$ & $4-\mathrm{dU}$ & $\mathrm{DW}$ \\
\hline 1 & $\mathrm{Y}=\alpha+\beta_{1} X+\varepsilon$ & 1,5981 & 1,6521 & 2,3479 & 1,804 \\
2 & $\mathrm{Y}=\alpha+\beta_{1} X+\beta_{2} Z+\beta_{3} \mathrm{XZ}+\varepsilon$ & 1,5709 & 1,6802 & 2,3198 & 1,783 \\
\hline
\end{tabular}

Sumber: Data Penelitian, 2020

Berdasarkan Tabel 6, dapat dilihat bahwa nilai Durbin-Watson (DW) pada model pertama sebesar 1,804 dan model kedua sebesar 1,783. Nilai 4-dU untuk model regresi pertama adalah $4-1,6521=2,3479$. Nilai DW pada model pertama adalah 1,804 (dU < DW < (4-dU), yaitu 1,5981 < 1,804 < 2,3479) dapat disimpulkan bahwa model regresi pertama tidak terdapat gangguan autokorelasi. Nilai DW pada model kedua sebesar 1,783 (dU < DW < (4-dU), yaitu 1,5709 < 1,783 < 2,3198) dapat dijelaskan bahwa model regresi kedua tidak terdapat gangguan autokorelasi. Analisi regresi sederhana dan analisis regresi moderasi dilakukan untuk menguji hipotesis. Hasil pengujian dapat dilihat pada Tabel 7 dan 8 , sebagai berikut.

Tabel 7. Hasil Uji Analisis Regresi

\begin{tabular}{|c|c|c|c|c|}
\hline \multirow[t]{2}{*}{ Model } & \multicolumn{2}{|c|}{ Unstandardized Coefficient } & \multirow{2}{*}{$\begin{array}{c}\begin{array}{c}\text { Standardized } \\
\text { Coefficient }\end{array} \\
\text { Beta }\end{array}$} & \multirow[t]{2}{*}{ Sig. } \\
\hline & $B$ & Std. Error & & \\
\hline (Constant) & $-0,073$ & 0,855 & & 0,932 \\
\hline CSRI (X) & $-0,462$ & 1,007 & $-0,254$ & 0,000 \\
\hline \multicolumn{4}{|c|}{ R Square $=0,206$} & $F=5,211$ \\
\hline \multicolumn{4}{|c|}{ Adj. $R$ Square $=0,201$} & Sig. $=0,007$ \\
\hline
\end{tabular}

Sumber: Data Penelitian, 2020

Berdasarkan hasil analisis regresi linear sederhana dan analisis regresi moderasi seperti yang disajikan pada Tabel 7 dan 8, maka dapat disusun persamaan regresi moderasi sebagai berikut.

$$
\begin{gathered}
Y=-0,073-0,462 X+\varepsilon \\
Y=1,814-1,660 X-1,290 Z-0,211 X Z+\varepsilon
\end{gathered}
$$


Hipotesis pertama $\left(\mathrm{H}_{1}\right)$ menyatakan bahwa pengungkapan CSR berpengaruh negatif pada penghindaran pajak. Berdasarkan hasil pengujian pada Tabel 7, menunjukkan bahwa variabel pengungkapan CSR (X) memiliki koefisien beta negatif 0,462 dengan tingkat Signifikansi 0,000. Nilai Signifikansi lebih kecil dari $\alpha=0,05(0,000<0,05)$, yang berarti hasil uji Signifikan, maka hipotesis pertama diterima. Hasil menunjukkan bahwa profitabilitas berpengaruh negatif pada penghindaran pajak. Pengungkapan CSR dan kepatuhan pajak memiliki korelasi positif (Hidayat et al., 2018). Perusahaan yang sadar akan tanggung jawab sosial dan lingkungan cenderung lebih sadar akan kewajibannya dalam membayar pajak. Perusahaan yang telah membayar kewajiban pajaknya berarti perusahaan tersebut telah berkontribusi dalam membantu pembangunan dan meningkatkan kesejahteraan masyarakat. Hasil penelitian ini mendukung teori legitimasi yang menyatakan bahwa perusahaan mengungkapkan aktivitas CSR yang telah dilakukan dan melakukan pembayaran pajak sesuai dengan jumlah yang telah ditentukan sebagai bentuk tanggung jawabnya terhadap sosial. Hasil penelitian ini mendukung penelitian yang dilakukan oleh Wijaya (2019) serta Prasista \& Setiawan (2016) yang menemukan hasil bahwa pengungkapan CSR berpengaruh negatif pada penghindaran pajak.

Tabel 8. Hasil Uji Hasil Uji MRA

\begin{tabular}{lcccc}
\hline \multirow{2}{*}{ Model } & \multicolumn{2}{c}{ Unstandardized Coefficient } & $\begin{array}{c}\text { Standardized } \\
\text { Coefficient }\end{array}$ & \multirow{2}{*}{ Sig. } \\
\cline { 2 - 4 } & $\mathrm{B}$ & Std. Error & Beta & \\
\hline (Constant) & 1,814 & 0,810 & & 0,028 \\
CSRI (X) & $-1,660$ & 2,625 & $-0,077$ & 0,000 \\
ROA (Z) & $-1,290$ & 1,842 & $-0,151$ & 0,009 \\
CSRI_ROA (XZ) & $-0,211$ & 0,147 & $-0,307$ & 0,016 \\
R Square $=0,384$ & & & & $\mathrm{~F}=11,137$ \\
Adj. R Square $=0,376$ & & & & Sig. $=0,000$ \\
\hline
\end{tabular}

Sumber: Data Penelitian, 2020

Hipotesis kedua $\left(\mathrm{H}_{2}\right)$ menyatakan bahwa profitabilitas memoderasi pengaruh pengungkapan CSR pada penghindaran pajak. Berdasarkan hasil pengujian pada Tabel 8, menunjukkan bahwa variabel interaksi pengungkapan CSR dengan profitabilitas (XZ) memiliki koefisien beta negatif 0,211 dengan tingkat Signifikansi 0,016. Nilai Signifikansi lebih kecil dari $a=0,05(0,016<0,05)$ yang berarti hasil uji Signifikan, maka hipotesis kedua diterima. Hasil menunjukkan bahwa profitabilitas mampu memoderasi pengaruh pengungkapan CSR pada penghindaran pajak.

Perusahaan yang memiliki nilai profitabilitas tinggi cenderung melaporkan pajaknya dengan jujur dibandingkan dengan perusahaan yang mempunyai profitabilitas rendah. Perusahaan dengan laba yang tinggi memiliki keyakinan dan menganggap bahwa perusahaan mampu mengatur pendapatan sehingga perusahaan tersebut cenderung patuh terhadap kewajibannya untuk membayar pajak (Dwiyanti \& Jati, 2019). Perusahaan yang memiliki tingkat kesadaran akan tanggung jawab sosial dan lingkungan yang tinggi serta jujur dalam pengelolaan laba cenderung tidak agresif dalam hal perpajakan karena perusahaan sadar akan 
pentingnya legitimasi atau citra yang diberikan oleh masyarakat. Perusahaan dengan profitabilitas yang tinggi selalu berusaha untuk mempertahankan citra positif di masyarakat, tujuannya agar perusahaan dapat going concern. Perusahaan yang memiliki profitabilitas tinggi cenderung lebih sadar dengan tanggung jawabnya terhadap stakeholder, karena perusahaan sadar bahwa laba tinggi yang dihasilkan ditunjang oleh dukungan dari seluruh stakeholder. Bentuk tanggung jawab yang dapat diberikan perusahaan kepada stakeholder adalah melalui pembayaran pajak kepada pemerintah.

\section{SIMPULAN}

Berdasarkan pembahasan yang telah diuraikan sebelumnya, maka hasil penelitian ini menunjukkan bahwa, pertama, pengungkapan Corporate Social Responsibility (CSR) berpengaruh negatif pada penghindaran pajak. Hal ini menunjukkan tingkat pengungkapan CSR yang tinggi cenderung semakin tinggi pula kesadaran tanggung jawab perusahaan untuk membayar pajak. Kedua, profitabilitas yang diproksikan dengan Return on Assets (ROA) mampu memoderasi pengaruh pengungkapan CSR pada penghindaran pajak. Hal ini menunjukkan bahwa perusahaan dengan tingkat profitabilitas tinggi serta pengungkapan CSR yang luas cenderung mengurangi tindakan penghindaran pajak.

Adapun saran yang dapat diberikan yaitu, pertama, bagi manajemen perusahaan, diharapkan dapat mempertahankan citra perusahaan dengan tidak melakukan tindakan penghindaran pajak. Kedua, bagi peneliti selanjutnya, hasil penelitian ini tidak dapat digeneralisasi untuk seluruh perusahaan yang terdaftar di Bursa Efek Indonesia (BEI), karena terbatas pada perusahaan pertambangan sebagai ruang lingkup penelitian. Bagi peneliti selanjutnya juga diharapkan untuk mempertimbangkan variabel lain yang dapat memengaruhi penghindaran pajak pada perusahaan sektor lainnya.

\section{REFERENSI}

Armstrong, C. S., Blouin, J. L., Jagolinzer, A. D., \& Larcker, D. F. (2015). Corporate governance, incentives, and tax avoidance. Journal of Accounting and Economics, 60(1), 1-17. https:// doi.org/10.1016/j.jacceco.2015.02.003

Budhi, N., \& Dharma, S. (2017). Pengaruh Corporate Social Responsibility Dan Capital Intensity Terhadap Tax Avoidance. E-Jurnal Akuntansi, 18(1), 529-556.

Carpenter, T., \& Jones, K. (2015). Online Early - Preprint of Accepted Manuscript preprint accepted manuscript. Journal of International Accounting Research, 90(4), 1395-1435. https:/ / doi.org/10.2308/accr-50982

Chariri, (2008). Kritik Sosial Atas Pemakaian Teori Dalam Penelitian Pengungkapan Sosial dan Lingkungan. Jurnal Maksi, Vol. 8 No.2, hal 151-169.

Chen, S., Chen, X., Cheng, Q., \& Shevlin, T. (2010). Are family firms more tax aggressive than non-family firms? Journal of Financial Economics, 95(1), 41-61. https://doi.org/10.1016/j.jfineco.2009.02.003

Chen, Y., Ge, R., Louis, H., \& Zolotoy, L. (2019). Stock liquidity and corporate tax avoidance. Review of Accounting Studies, 24(1), 309-340. https://doi.org/10.1007/s11142-018-9479-6

Damayanti, F., \& Susanto, T. (2016). Pengaruh Komite Audit, Kualitas Audit, Kepemilikan Institusional, Risiko Perusahaan Dan Return on Assets 
Terhadap Tax Avoidance. Esensi, 5(2), 187-206. https://doi.org/10.15408/ess.v5i2.2341

Darmawan, I., \& Sukartha, I. (2014). Pengaruh Penerapan Corporate Governance, Leverage, Roa, Dan Ukuran Perusahaan Pada Penghindaran Pajak. E-Jurnal Akuntansi, 9(1), 143-161.

Davis, A. K., Guenther, D. A., Krull, L. K., \& Williams, B. M. (2016). Do socially responsible firms pay more taxes? Accounting Review, 91(1), 47-68. https://doi.org/10.2308/accr-51224

Dwiyanti, I. A. I., \& Jati, I. K. (2019). Pengaruh Profitabilitas, Capital Intensity, dan Inventory Intensity pada Penghindaran Pajak. E-Jurnal Akuntansi, 27, 2293. https://doi.org/10.24843/ eja.2019.v27.i03.p24

Dyreng, S. D., Hanlon, M., \& Maydew, E. L. (2010). The effects of executives on corporate tax avoidance. Accounting Review, 85(4), 1163-1189. https://doi.org/10.2308/accr.2010.85.4.1163

Gaaya, S., Lakhal, N., \& Lakhal, F. (2017). Does family ownership reduce corporate tax avoidance? The moderating effect of audit quality. Managerial Auditing Journal, 32(7), 731-744. https:/ / doi.org/10.1108/MAJ-02-2017-1530

Global Reporting Initiative. (2016). Pedoman Pelaporan Keberlanjutan G4. Global Reporting Initiative. www.globalreporting.org

Gulzar, M. A., Cherian, J., Sial, M. S., Badulescu, A., Thu, P. A., Badulescu, D., \& Khuong, N. V. (2018). Does corporate social responsibility influence corporate tax avoidance of Chinese listed companies? Sustainability (Switzerland), 10(12), 1-12. https://doi.org/10.3390/su10124549

Hidayat, K., Ompusunggu, A. P., \& H. Suratno, H. S. (2018). Pengaruh Corporate Social Responsibility Terhadap Agresivitas Pajak Dengan Insentif Pajak Sebagai Pemoderasi (Studi Pada Perusahaan Pertambangan Yang Terdaftar Di Bei). JIAFE (Jurnal Ilmiah Akuntansi Fakultas Ekonomi), 2(2), 39-58. https://doi.org/10.34204/jiafe.v2i2.543

Hidayat, W. W. (2018). Pengaruh Profitabilitas, Leverage Dan Pertumbuhan Penjualan Terhadap Penghindaran Pajak: Studi Kasus Perusahaan Manufaktur Di Indonesia. Jurnal Riset Manajemen Dan Bisnis, 3(1), 19-26.

Journal, D., \& Accounting, O. F. (2017). Pengaruh Pengungkapan Corporate Social Responsibility Terhadap Agresivitas Pajak Dengan Moderasi Kepemilikan Saham Oleh Keluarga. Pengaruh Pengungkapan Corporate Social Responsibility Terhadap Agresivitas Pajak Dengan Moderasi Kepemilikan Saham Oleh Keluarga, 6(4), 324-336.

Kalbuana, N., Purwanti, T., \& Agustin, N. H. (2017). Pengaruh Kepemilikan Manajerial, Beban Pajak Tangguhan, dan Tingkat Pajak Efektif Terhadap Penghindaran Pajak di Indonesia. Magistra, 9(100), 26-35.

Kementerian Keuangan Republik Indonesia. (2020). APBN Kita Januari 2020. https://www.kemenkeu.go.id/publikasi/apbn-kita/

Keung Hoi, C., Wu, Q., \& Zhang, H. (2013). Is Corporate Social Responsibility (CSR) Associated with Tax Avoidance? Evidence from Irresponsible CSR Activities. In The Accounting Review (Vol. 88).

Kim, J., \& Im, C. (2017). Study on corporate social responsibility (CSR): Focus on tax avoidance and financial ratio analysis. Sustainability (Switzerland), 9(10), 1-15. https://doi.org/10.3390/su9101710 
Klassen, J. K., Lisowsky, P., \& Mescall, D. (2016). The role of auditors, NonAuditors, and internal tax departments in corporate tax aggressiveness. Accounting Review, 91(1), 179-205. https:/ / doi.org/10.2308/accr-51137

Laguir, I., Staglianò, R., \& Elbaz, J. (2015). Does corporate social responsibility affect corporate tax aggressiveness? Journal of Cleaner Production, 107, 662-675. https://doi.org/10.1016/j.jclepro.2015.05.059

López-González, E., Martínez-Ferrero, J., \& García-Meca, E. (2019). Does corporate social responsibility affect tax avoidance: Evidence from family firms. Corporate Social Responsibility and Environmental Management, 26(4), 819-831. https://doi.org/10.1002/csr.1723

Luh, N., \& Puspita, P. (2017). Pengaruh Ukuran Perusahaan, Leverage, Profitabilitas dan Corporate Social Responsibility Terhadap Penghindaran Pajak (Tax Avoidance). E-Jurnal Akuntansi, 21, 882-911. https:// doi.org/10.24843/EJA.2017.v21.i02.p01

Mao, C. W. (2019). Effect of corporate social responsibility on corporate tax avoidance: evidence from a matching approach. Quality and Quantity, 53(1), 49-67. https:/ / doi.org/10.1007/s11135-018-0722-9

Mumtahanah, Shofia Nur \& Septiani, Aditya, (2017). Pengaruh Pengungkapan Corporate Social Responsibility Terhadap Agresivitas Pajak Dengan Moderasi Kepemilikan Saham Oleh Keluarga (Studi Pada Perusahaan Pertambangan Yang Terdaftar Di Bursa Efek Indonesia Tahun 2013-2015). Diponegoro Journal of Accounting, Volume 6, Nomor 4 hal 1-13

Mustika, Ratnawati, V., \& Silfi, A. (2017). Pengaruh Corporate Social Responsibility, Ukuran Perusahaan, Profitabilitas, Leverage, Capital Intensity dan Kepemilikan Keluarga terhadap Agresivitas Pajak (Studi Empiris Pada Perusahaan Pertambangan dan Pertanian yang terdaftar di Bursa Efek Indonesia P. Jurnal Online Mahasiswa Fakultas Ekonomi Universitas Riau, 4(1), 1886-1900.

Muzakki, M. R., \& Darsono. (2015). Pengaruh Corporate Social Responsibility Dan Capital Intensity Terhadap Penghindaran Pajak. E-Jurnal Akuntansi, 4(3), 445452.

Novitasari, S., Ratnawati, V., \& Silfi, A. (2016). Pengaruh Manajemen Laba, Corporate Governance, Dan Intensitas Modal Terhadap Agresivitas Pajak Perusahaan (Studi Empiris pada Perusahaan Property dan Real Estate yang Terdaftar di BEI Periode Tahun 2010-2014). Jurnal Online Mahasiswa Fakultas Ekonomi Universitas Riau, 4(1), 1901-1914.

Oktamawati, M. (2017). Pengaruh Karakter Eksekutif, Komite Audit, Ukuran Perusahaan, Leverage, Pertumbuhan Penjualan, Dan Profitabilitas Terhadap Tax Avoidance. Jurnal Akuntansi Bisnis, 15(1), 23-40. https://doi.org/10.24167/JAB.V15I1.1349

Pramudito, B. W., \& Sari, M. M. R. (2015). Pengaruh Konservatisme Akuntansi, Kepemilikan Manajerial Dan Ukuran Dewan Komisaris Terhadap Tax Avoidance. E-Jurnal Akuntansi, 13(3), 737-752.

Prasista, P., \& Setiawan, E. (2016). Pengaruh Profitabilitas Dan Pengungkapan Corporate Social Responsibility Terhadap Agresivitas Pajak Penghasilan Wajib Pajak Badan. E-Jurnal Akuntansi, 17(3), 2120-2144.

Puji, A. T., Rahmawati, Aryani, Y. A., \& Setiawan, D. (2019). The effect of family 
ownership on aggressive tax avoidance in Indonesia. EJournal of Tax Research, 17(1), 105-117.

Puspita, D., \& Febrianti, M. (2018). Faktor-faktor yang memengaruhi penghindaran pajak pada perusahaan manufaktur di bursa efek Indonesia. Jurnal Bisnis Dan Akuntansi, 19(1), 38-46. https://doi.org/10.34208/jba.v19i1.63

Ratmono, D., \& Sagala, W. M. (2016). Pengungkapan Corporate Social Responsibility (CSR) Sebagai Sarana Legitimasi: Dampaknya Terhadap Tingkat Agresivitas Pajak. Nominal, Barometer Riset Akuntansi Dan Manajemen, 4(2), 16-30. https:// doi.org/10.21831/nominal.v4i2.7997

Sulistyowati, \& Ulfah, L. A. (2016). Pengaruh Pengungkapan Corporate Social Responsibility, Profitabilitas, Dan Leverage Terhadap Agresivitas Pajak Pada Perusahaan Manufaktur Yang Terdaftar Di Bursa Efek Indonesia Tahun 2013-2015. Jurnal Ekonomi UMRAH, 15(2), 1-15.

Wijaya, D. (2019). Pengaruh Pengungkapan Corporate Social Responsibility, Leverage, Dan Kepemilikan Manajerial Terhadap Agresivitas Pajak. Widyakala Journal, 6(1), 55. https:// doi.org/10.36262/widyakala.v6i1.147 